\title{
Mechanical characteristics of Circular cable roof systems
}

\author{
Prof Kanggeun Park \\ Department of Architectural Engineering \\ I'ST Institute of Technology, Seoul, South Korea \\ $\mathrm{PhD}$ Dongwoo Lee \\ Department of Architectural Engineering \\ I'ST Institute of Technology, Seoul, South Korea \\ Prof Mijin Park \\ Department of Architectural Engineering \\ Incheon National University, Incheon, South Korea
}

\begin{abstract}
A circular cable roof system in this study is a type of structures in which the part of entire roof can be opened and closed. The circular cable roof system with reverse curvature cable trusses can effectively carry vertical load in up and downward direction, the outer roof is a fixed lightweight membrane and the middle part is a roof system that can be opened and closed. The retractable roof is designed as the control system of optimum environment in which the part of roof can be open or closed to overcome extreme outdoor environment such as extreme hot, cold weather or strong sunlight. This research is analyzed the mechanical characteristics of retractable circular cable roof systems for the internal force of cables and the deflection of a roof according to hub or post heights. The structural advantages of a radial cable roof system, a spoke wheel cable roof system and a cable network system are compared for the results of geometrical nonlinear analysis by using Midas 2016 software.
\end{abstract}

Keywords - Circular Cable Roof, Retractable Roof, Mechanical Characteristics, Geometrical Nonlinear Analysis

\section{INTRODUCTION}

Radial cable roof systems with an outer circular ring can be defined as a self-equilibrium roof structures which consists of a central hub and radial tension cable trusses, the structural principle is a kind of tensegrity systems by using compression members and continuous cable members. The advantage of the cable roof systems is the weight of roof dramatically can reduce that the span become large, and the roof weight normally is $0.1-0.3 \mathrm{kN} / \mathrm{m}^{2}$. The selfequilibrating effect and the lightness of the structural systems are efficiently utilized to the large roof of sports arena with span $100-200 \mathrm{~m}$. But a general cable system is too flexible, the displacements are very large. The circular cable roof system with reverse curvature cable trusses can effectively carry vertical load in up and downward direction, and cables are stabilized by connecting and pre-stressing the upper and lower cable by hangar cables. A retractable roof has the control system of optimum to overcome extreme outdoor environments such as extreme hot, cold weather or strong sunlight [1-2].

This study is aimed to provide the information of design methodology for the development of effective systems in the lightweight roof system of a large span cable structure. The analytical models of nonlinear analysis are a radial cable roof system, a cable spoke wheel system and a cable network system with membrane. A structural analysis of cable structures having a cable element and a triangular membrane element for the nonlinear analysis is relatively complex than other rigid structures. The reasons are large displacements by large flexibility. Cables is tension only members that cannot transmit shear forces, compression forces and bending moments. The pre-stress is applied to cables in order to increase the structural rigidity, but divergence of iteration analysis occurs rather frequently. Therefore, the geometric nonlinear analysis of cable systems does not exhibit typical nonlinear behavior, it is necessary to handle initial pre-stress forces, iterative numbers of load step, a data of convergence criteria, an artificial control data of negative cable and a choice of nonlinear iterative method. In this paper, it will be compared for the tensile force of cables and deflection of a roof for retractable circular cable structures according to the height of roof posts [3-10]. 


\section{TENSile StREngth EQuATION OF CABLE}

Wire rope is a type of cable which consists of several strands twisted into a helix. Steel wires are normally made of non-alloy steel with a carbon content of 0.4 to $0.95 \%$. Cross lay strands have the wires of the layers cross each other, mostly use parallel lay strands. Spiral ropes have an assembly of layers of wires laid helically over a center being laid in the opposite direction. Locked coil ropes have one or more outer layers of profile wires to prevent the penetration of dirt and water. Stranded ropes are an assembly of several strands laid helically in one or more layers around a core. Fiber cores are the most flexible and elastic. Independent wire rope core (IWRC) is the most durable for the condition of environments. The tensile strength of a cable Ts can be calculated by an equation of Table- 1 . Sc, $\mathrm{Rc}$ and Ns are section compaction coefficient, rotating coefficient and nominal strength, respectively. As is the gross area of a cable [3-6].

Table - 1 Tensile strength equation of cables

\begin{tabular}{|c|c|c|c|}
\hline Cable types & $\begin{array}{c}\text { Section compaction } \\
\text { coefficient (Sc) }\end{array}$ & $\begin{array}{c}\text { Rotating coefficient } \\
(\mathrm{Rc})\end{array}$ & $\begin{array}{c}\text { Nominal strength } \\
(\mathrm{Ns}, \mathrm{MPa})\end{array}$ \\
\hline Strand rope & 0.39 & 0.87 & 1670 \\
CFRC rope & 0.34 & 0.83 & 1670 \\
Spiral rope & 0.24 & 0.88 & 1670 \\
Locked coil rope & 0.18 & 1.90 & 1470 \\
\hline Parallel strand rope & 0.10 & 1.00 & 1570 \\
Non-grout parallel rope & 0.19 & 1.00 & 1860 \\
PC strand(7 wire) & 0.23 & 1.00 & 1810 \\
PC strand(19 wire) & 0.16 & Ts = As x (1-Sc) $\times$ Rc x Ns \\
\hline Tensile strength equation & \multicolumn{3}{c}{} \\
\hline
\end{tabular}

\section{STRUCTURAL SySTEMS OF RADIAL CABLE RoOF}

Natural spider webs as shown in Figure 1 is an analogical prototype structure to a radial cable net, even though spider nets have no any stable or rigidity and valley cables. A very similar structure is a typical radial cable net system consists of tension members. Such tension members include inner hoop cables, upper ridge cables and bottom valley cables along radial direction, and bracing cables extending there between. These cable structures can be found sports arena such as tennis court roof, football stadium roof and retractable cable truss roof systems which have span100-200 $\mathrm{m}$ as shown in Figure $2[4,8]$.
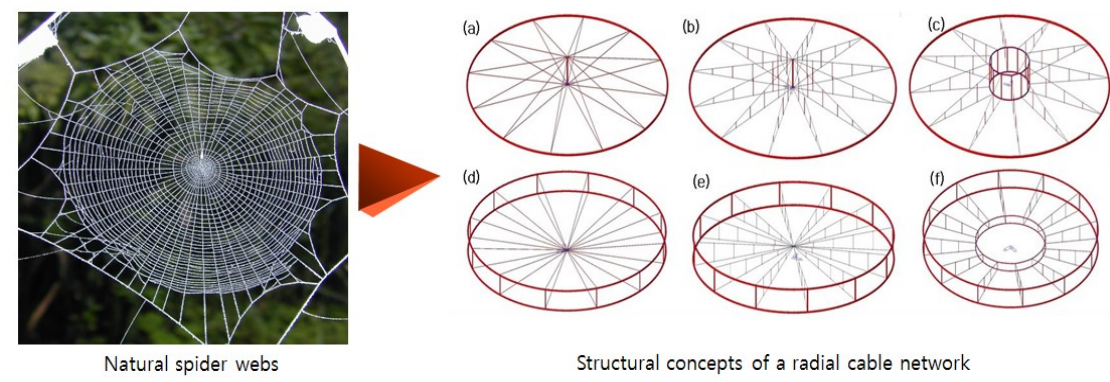

Structural concepts of a radial cable network

Figure 1. Structural concepts inspired by natural spider webs

The nonlinearity of general structures is due to the nonlinear behavior of the material, the geometric nonlinearity or combined effects. Cables have a nonlinear behavior that has large displacement. A radial cable roof system consists of a compressive outer ring, a central hub and radial tension cable spokes. The self-equilibrium and lightness of the structural system is efficiently used to the retractable large span cable roof as shown in Figure 1-3. A cable roof is too flexible and the displacement is too large, but the deflection of a roof is controlled by sag ratio and pre-stress. The cables are pre-stressed, and the structural rigidity of roof increased by pre-stressing. A cable truss roof system is formed by adding a set of cables with reverse curvature as shown in Figure 4. The double cable arrangement system works more efficiently as a load bearing system, pre-tensioning of the cables strongly makes the structural stiffness. Assembling the sets of cables having opposite curvature to each other, cable truss is able to carry vertical load in both upward and downward direction. The retractable roof is designed as a full control system to overcome extreme outdoor environments such as extreme hot, cold weather, strong wind or sunlight, and also the cable roof greatly can reduce the roof weight compared to other rigid structural system [3-10]. 


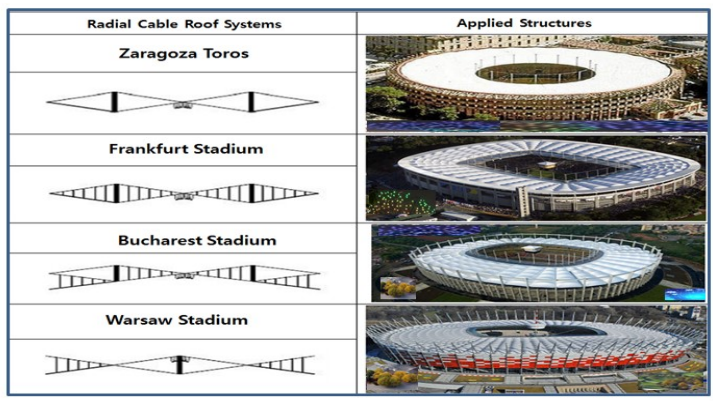

Figure 2. Radial cable roof systems and applied examples

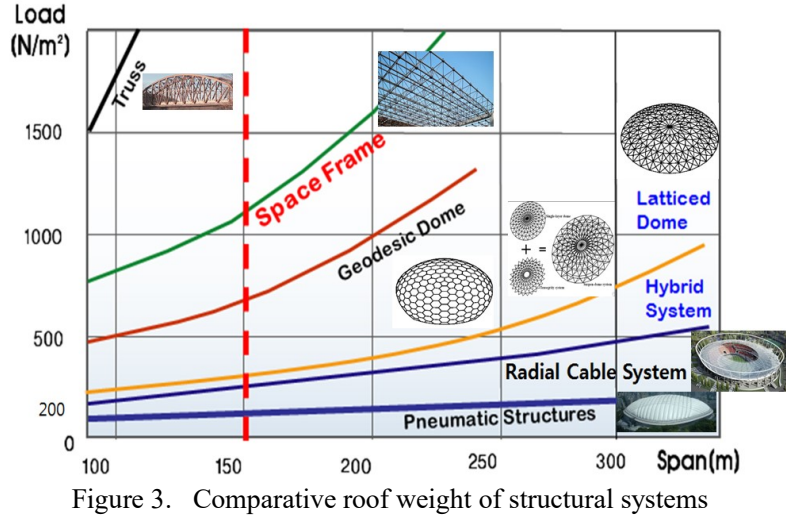

\begin{tabular}{|c|c|c|c|c|c|c|}
\hline \multicolumn{2}{|c|}{ Outer stationary roof } & $\square$ & Inner retractable roof & 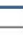 & Combination & Examples \\
\hline$<$ & $\square$ & ${ }^{+}$ & & $=$ & $\rightarrow \mathrm{I}-\mathrm{I}$ & Zaragoza \\
\hline 시 & Ш山् & + & DUIn & $=$ & 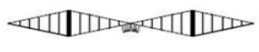 & $\begin{array}{c}\text { Frankfurt } \\
\text { Rothenbaum }\end{array}$ \\
\hline IIIT & स्या & ${ }^{+}$ & DIDDins & $=$ & 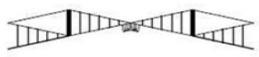 & Bucharest \\
\hline IIIT & स्या & + & $\pi$ & $=$ & IIIm $\mathrm{t}$ - याया & Warsaw \\
\hline
\end{tabular}

Figure 4. Retractable cable roof system combined by outer stationary roof and inner retractable roof

\section{Mechnical Characteristics of CirCular CABle RoOf Systems}

\section{A. Cable spoke wheel roof system -}

The objective of this study is to analysis the mechanical characteristics and nonlinear behaviors on the geometric nonlinear analysis of a cable spoke wheel roof system with span $200 \mathrm{~m}$ for the retractable and lightweight roof. The weight of a cable spoke wheel roof as shown in Figure 5 greatly can reduce, and this cable roof system can easily make the required rigidity by the sag ratio and pretension forces. Determining the pretension and initial sag of cable roof system is essential in a design process, and the shape of roof is changed by pretension. The flexible cable system has greatly affected on the sag and pretension [9]. This study is carried out comparing the tensile force and deflection of a cable spoke wheel system by the post height of center hub for the vertical load $0.25,0.5,0.75$ and 1.0 $\mathrm{kN} / \mathrm{m}^{2}$, respectively. 

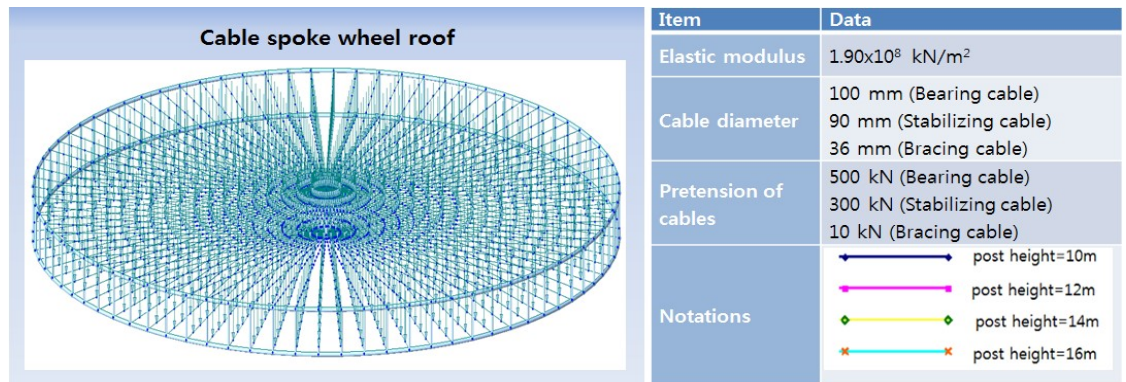

Figure 5. Total structural system of a cable spoke wheel roof

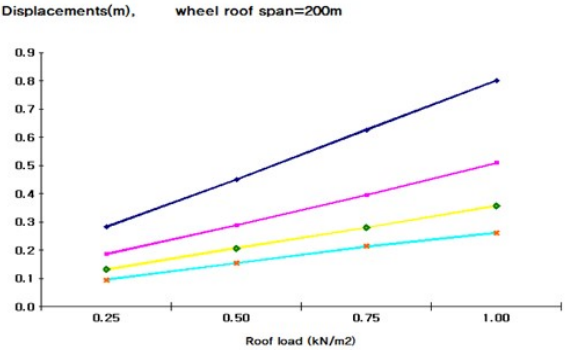

(a) Displacements of a cable spoke wheel roof by post height 10,12, 14, 16m (span=200m)

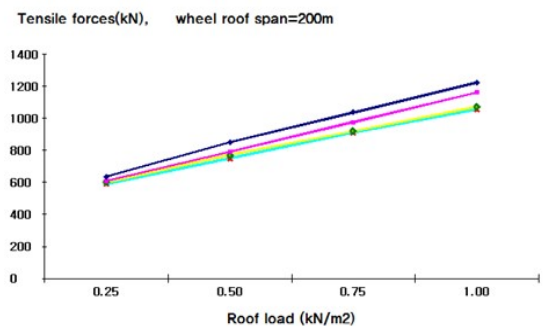

(c) Tensile forces of stabilizing cables by post height $10,12,14,16 \mathrm{~m}(\mathrm{span}=200 \mathrm{~m})$

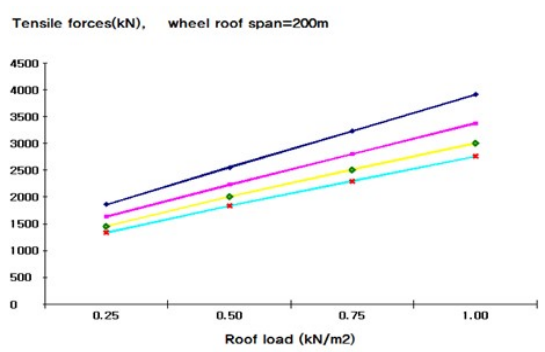

(b) Tensile forces of bearing cables by post height 10 . 12. $14,16 \mathrm{~m}($ span=200m)

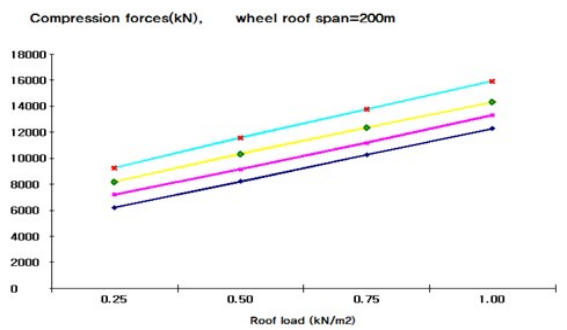

(d) Compression forces of center post by height 16 . 14. $12,10 \mathrm{~m}($ span $=200 \mathrm{~m})$

Figure 6. Nonlinear analysis results of a cable spoke wheel roof (Increment steps=9000, Tolerance=1.0E-07)

\section{B. Radial cable roof system -}

The objective of this study is to analysis the mechanical characteristics for the geometric nonlinear behavior of a radial cable roof system as shown in Figure 7 for a retractable roof. A retractable cable roof system is a type of structures in which the part of entire roof can be opened and closed. The radial cable roof is an effective structural system for large span retractable roofs, the outer perimeter of the roof is a fixed membrane roof and the middle part is a roof that can be opened and closed [10]. It is analyzed the mechanical characteristics of a radial cable roof system by the height of roof posts. It will be investigated the tensile forces of bearing cables, stabilized cables, ring cables, and the deflection of roof according to the height of the post that affects the sag ratio of cable truss. The tensile force of the cables and the deflection of the roof are compared for the vertical load $0.25,0.5,0.75$ and 1.0 $\mathrm{kN} / \mathrm{m}^{2}$. 

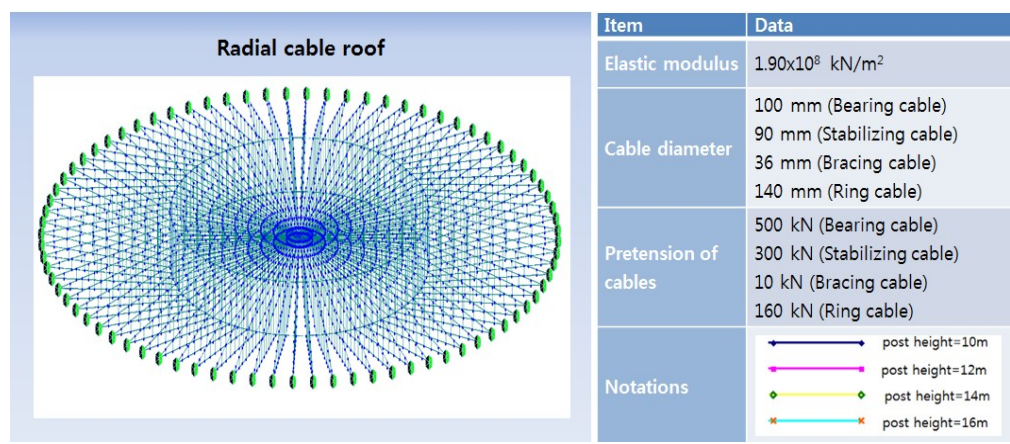

Figure 7. Total structural system of a radial cable roof

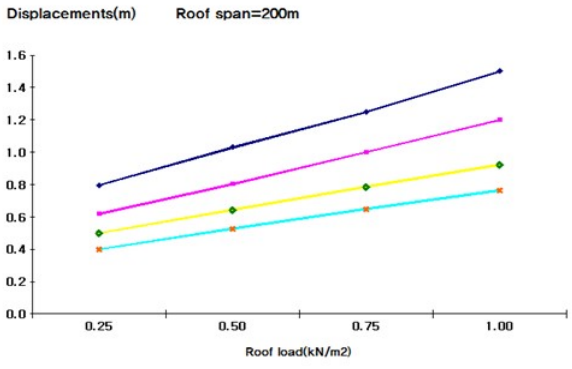

(a) Displacements of a radial roof system by post height 10,12, 14, 16m (span=200m)

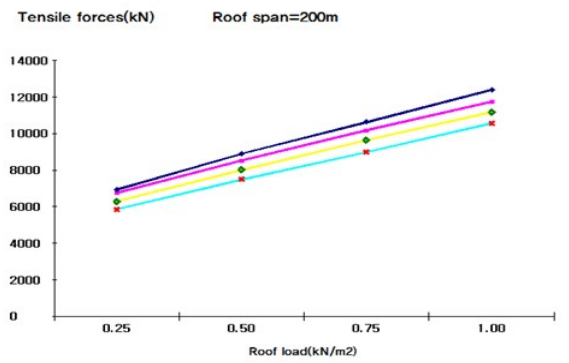

(c) Tensile forces of ring cables by post height 10 , 12, $14,16 \mathrm{~m}(\mathrm{span}=200 \mathrm{~m})$

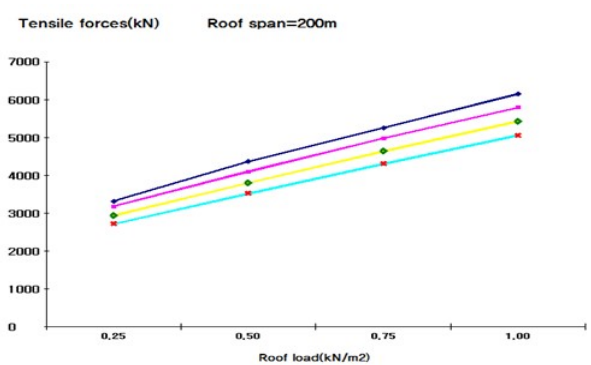

(b) Tensile forces of bearing cables by post height 10 . 12. $14,16 \mathrm{~m}($ span=200m)

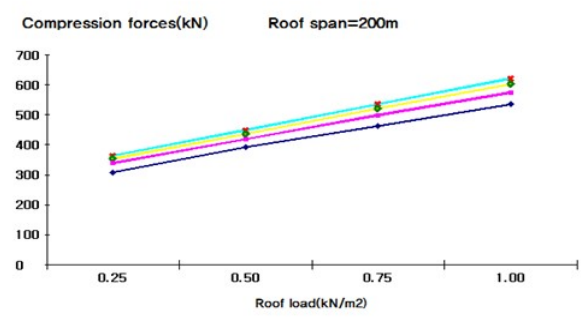

(d) Compression forces of roof posts by height 16,14 , 12. $10 \mathrm{~m}(\mathrm{span}=200 \mathrm{~m})$

Figure 8. Nonlinear analysis results of a radial cable roof (Increment steps $=9000$, Tolerance $=1.0 \mathrm{E}-07$ )

\section{Circular cable-membrane roof-}

The objective of this study is to estimate the mechanical characteristics and nonlinear behaviors for the geometric nonlinear analysis of a curved cable-membrane roof system with span $100 \mathrm{~m}$. The curved cable-membrane roof system can transmit vertical loads in up and downward direction, and work effectively as a load bearing structure to resists self-weight, snow and wind load. It is carried out analyzing and comparing the tensile forces and deflection of curved cable network roof systems by vertical loads.
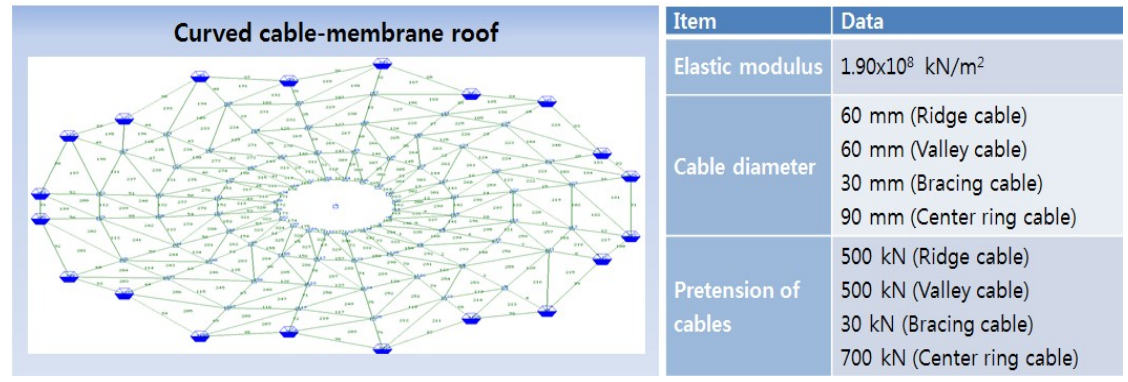
Figure 9. An anytical model of a curved cable network with membrane

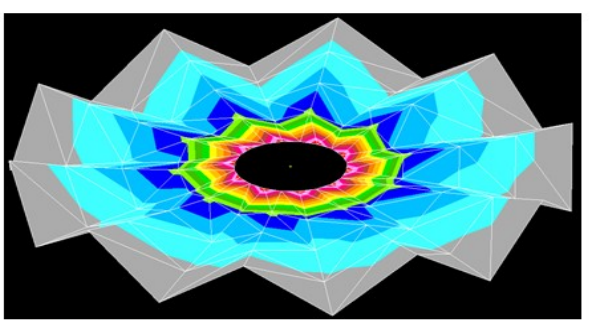

(a) Deflection contour of a circular curved roof (range $=0-0.559 \mathrm{~m}$, load $=1 \mathrm{kN} / \mathrm{m}^{2}$ )

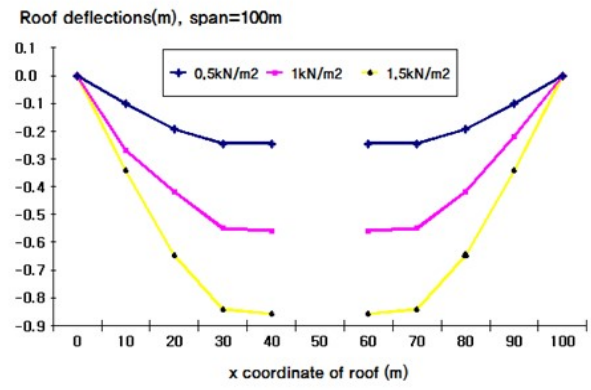

(c) Comparative deflection of a circular roof

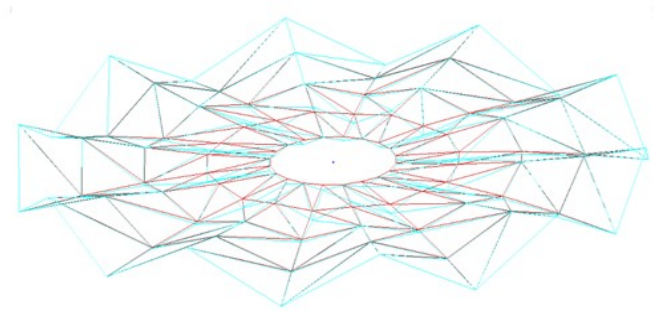

(b) Deformation of a circular roof

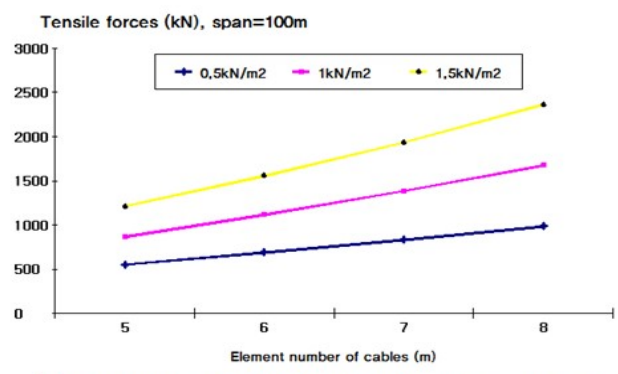

(d) Comparative tensile forces of bearing cables for vertical loads

Figure 10. Nonlinear analysis results of a curved cable network with membrane(Increment steps $=300$, Tolerance $=1.0 \mathrm{E}-06)$

\section{V.CONCLUSION}

The research is to analysis the mechanical characteristics and nonlinear behaviors for the geometric nonlinear analysis of a cable spoke wheel system, a radial cable roof system and a curved cable-membrane roof system.

(a) A natural spider web is a kind of analogical prototype structure for radial cable roof systems. A nature inspired design of a cable system is not to replicate the natural forms, but to understand the rules and systems governing those forms. The design concept seeks to exploit new ideas such as creative designs and effective systems in nature.

(b) The double arrangements of a spoke wheel system with reverse curvature by an X form works more effectively as a load resistance system, the pretension can easily increase the structural stiffness of an overall roof. The cable truss system can carry vertical load in up and downward direction, and act effectively as load bearing elements. The cable roof system with X-shaped reverse curvature is a kind of very lightweight and little deformation systems that can resist vertical loads.

(c) The spoke wheel roof system is structurally more advantageous than the radial cable roof system because it has an X-shaped cable truss system, and the slope of the roof is easily controlled by the height of a center hub.

(d) The radial cable roof system is composed of the reverse direction of bearing cables and stabilized cables by roof posts, and the inclination of the roof is controlled by the height of roof post. The entire roof is lifted up by the tension of a lower ring cable connecting the roof posts to form a structural system.

(e) The radial cable roof system and the cable spoke wheel roof system are need to a compression member in a roof, but the curved cable network system does not need the compression members. The curved cable network roof system is composed of cables and membrane that only can transmit the tensile forces, the weight of roof can be dramatically reduced for long span roof. With the sets of cables having opposite curvature to each other, a curved cable network is able to resist vertical load in both upward and downward direction.

(f)As a result of the geometric nonlinear analysis for the whole roof, the tensile strength of the cable and the compressive force of the center post increased almost proportionally according to the nodal loads converted into the roof load.

(g) As the sag ratio by roof slope increased, the tensile strength of cables decreased and the compressive force of the roof post increased almost proportionally. 


\section{REFERENCES}

[1] G.R. Monforton and N.M. El-Hakim, "Analysis of Truss-cable Structures, Computer \& Structures 11," pp. 327-335, 1980

[2] H.T. Thai, S.E. Kim, "Nonlinear static and dynamics analysis of cable structures," Finite Element Analysis and Design 47, pp.237-246, 2011

[3] K.G. Park, S.J. Lee, D.W. Lee, "A Study on the Structural System of Flexible Large Span Spatial Roofs Using Steel Cables," Journal of The Residential Environment Institute of Korea, Vol.13(No.4), pp.393-404, 2015

[4] K.G. Park, D.W. Lee, "A Study on the Nature Inspiration Design of Eco-friendly Spatial Buildings", Journal of The Residential Environment Institute of Korea, Vol.13(No.5), pp.1-20, 2016

[5] K.G. Park, D.W. Lee, "Mechanical Characteristics of Cable Truss Roof Systems," Journal of Korean Association for Spatial Structures, Vol.16(No.2), pp.89-96, 2016

[6] K.G. Park, D.W. Lee, "Mechanical Behavior of Cable Net Structures Considering Sag Ratio," Journal of Korean Association for Spatial Structures, Vol.16(No.3), pp.47-58, 2016

[7] K.G. Park, D.W. Lee, T.J. Kwun, "Mechanical Characteristics of Large Span Spoke Wheel System", Proceedings of International Association for Spatial Structures(IASS), D1341, 2016

[8] K.G. Park, D.W. Lee, S.J. Lee, A Nature Inspired Design Philosophy of Spatial Structures, Proceedings of International Association for Spatial Structures(IASS), D1342, 2016

[9] K.G. Park, M.H. Lee, M.J. Park, "Nonlinear Behaviors of Cable Spoke Wheel Systems," Journal of Korean Association for Spatial Structures, Vol.17(No.1), pp.31-40, 2017

[10] K.G. Park, D.W. Lee, D.I. Choe, "Mechanical Characteristics of Retractable Radial Cable Roof Systems," Journal of Korean Association for Spatial Structures, Vol.17(No.2), pp.55-66, 2017

\section{ACKNOWLEDGEMENTS}

(a) This research was supported by a grant (17AUDP-B100343-03) from Architecture \& Urban Development Research Program funded by Ministry of Land, Infrastructure and Transport of Korean government.

(b) This research was supported by a grant (17CTAP-C115046-02) from Technology Advancement Research Program (TARP) funded by Ministry of Land, Infrastructure and Transport of Korean government 